\title{
KONVERGENSI TINGKAT PENDAPATAN STUDI KASUS 3 PROPINSI DI PULAU JAWA
}

\author{
Unggul Heriqbaldi \\ Fakultas Ekonomi Universitas Brawijaya
}

\begin{abstract}
The objective of this paper is to examine the income convergence in three provinces in Java island such as West Java, Central Java, and East Java during time period 2004-2007. Using two concepts of convergences which are $\beta$-convergence and $\sigma$ convergence, this paper show that in three regions there not found $\beta$-convergence and $\sigma$-convergence. This result indicated that in three provinces, if there were an increasing in Gross Domestic Regional Product (GDRP), it always espoused with enhancing in growth GDRP, and enhancing in the gap level in one regency to the other regency. This means that the estimation result exactly confirmed the happening of economy development with divergence not convergence.
\end{abstract}

Keywords: income convergences, regional economics, and divergence

\section{A. LATAR BELAKANG}

Pertumbuhan ekonomi regional dan konvergensi telah menjadi isu dalam berbagai penelitian terutama pada dekade 1990 an. Perkembangan ini tidak dapat dilepaskan dari perkembangan new growth theory dan new economic geography (NEG). New growth theory telah memberikan kontribusi signifikan dalam mengidentifikasi determinan pertumbuhan ekonomi, sedangkan NEG berperan sentral dalam menjelaskan berbagai disparitas pendapatan antar daerah.

Konsep konvergensi sendiri dalam ekonomi setidaknya mencakup dua aspek yaitu konvergensi pendapatan dan konvergensi dalam siklus bisnis. Kedua konsep tersebut secara teoritis dan empiris memiliki perbedaan. Terjadinya konvergensi pendapatan antar wilayah atau negara belum tentu menjamin adanya konvergensi siklus bisnis dalam waktu yang sama, demikian sebaliknya. Pengujian secara empirik diperlukan untuk mengetahui apakah beberapa wilayah atau negara memiliki karakteristik konvergensi pendapatan dan siklus bisnis.

Secara teoritis, adanya interkasi ekonomi yang mengarah pada integrasi antar wilayah atau negara akan mengarahkan pada kecenderungan konvergensi (Viner, 1950). Namun demikian, dalam NEG (Krugman, 1991) integrasi juga dapat menyebabkan terjadinya disparitas pendapatan. Teori NEG ini di antaranya didukung oleh penelitian Ben-David (2000) yang menyimpulkan bahwa pendapatan per kapita di seluruh dunia selama periode 1960-1985 cenderung divergen. Oleh karena itu, penelitian tentang konvergensi pendapatan antar negara atau wilayah dalam satu negara masih menjadi obyek yang menarik untuk ditelaah.

Paper ini bertujuan untuk menganalisis konvergensi pendapatan di masing-masing tiga Propinsi di Pulau Jawa, yaitu Jawa Timur, Jawa Tengah, dan Jawa Barat selama periode waktu 2004-2007. 


\section{B. KAJIAN TEORITIS}

Konsep konvergensi merupakan implikasi dari teori pertumbuhan yang dikembangkan pada dekade 1950 an. Pada beberapa artikel seperti Abramowitz (1956), Solow $(1956,1957)$ dan Swan (1956) diungkapkan bahwa selain akumulasi kapital dan tenaga kerja, terdapat faktor ketiga yang menjadi determinan pertumbuhan ekonomi yaitu perubahan teknologi, yang diperlakukan sebagai faktor eksogen di luar kedua faktor produksi di atas.

Teori ini mendasarkan diri pada teori fungsi produksi neoklasik yang memiliki karakteristik diminishing marginal return dan constant return to scale. Diminishing return ini menunjukkan hubungan antara output per worker dan capital per worker. Sebagai ilustrasi, negara yang dapat meningkatkan capital-labor ratio $(k)$ akan memiliki output per worker (y) yang lebih tinggi, namun demikian akumulasi kapital terkendala dengan adanya diminishing return. Ini artinya pada tingkat $k$ tertentu, dampak ( $k$ ) pada $(y)$ akan lebih besar pada kasus negara yang memiliki kapital terbatas (scarce) dibandingkan pada negara yang memiliki kapital relatif banyak (abundant).

Kemiringan fungsi produksi sendiri mengukur marginal product of capital $(\mathrm{MPK}=\mathrm{f}(\mathrm{k}+1)-$ $\mathrm{f}(\mathrm{k})$ ) di negara berkembang akan lebih besar dibandingkan di negara maju. Hal ini yang mejelaskan tingkat pertumbuhan di negara berkembang lebih tinggi dibandingkan di negara maju.

$$
\dot{k}=s f(k)-\delta k
$$

Persamaan (1) di atas menujukkan bagaimana perubahan capital-input per worker $\boldsymbol{k}$ dipengaruhi oleh saving $[\boldsymbol{s} \boldsymbol{f}(\boldsymbol{k})]$ dan depresiasi $(\boldsymbol{d} \boldsymbol{k})$. Di samping menunjukkan saving, $s f(k)$ juga adalah investment requirement per worker yang diperlukan agar capital labor ratio tidak mengalami perubahan.

Menurut Solow, steady-state condition akan terjadi dalam keadaan:

$$
s f(k *)-\delta k *=0
$$

Dalam keadaan steady-state, investment per worker hanya cukup untuk menutupi tingkat depreciation per worker, sehingga capital-labor ratio konstan. Jika pertumbuhan populasi dijadikan juga faktor yang mempengaruhi pertumbuhan ekonomi, maka pertumbuhan populasi dapat dipandang seperti tingkat depresiasi sehingga mengurangi pertumbuhan, secara fungsional dapat ditunjukkan sebagai berikut.

$$
\dot{k}=s f(k)-(n-\delta) k \text {. }
$$

$(n+d) k$ menjadi investment requirement agar capital-labor ratio tetap konstan. Ini artinya stok kapital harus tumbuh pada tingkat $(n+d)$. Jika $s f(k)>(n+d)$ maka terjadi capital deepening.

Gambar 1 di bawah ini menunjukkan secara grafis hubungan antara tabungan investasi, tingkat depresiasi, dan pertumbuhan penduduk. Dengan mengobservasi gambar tersebut dapat dinyatakan bahwa pada tingkat capital stock per worker $k, s f(k)$ yaitu tingkat tabungan atau investasi melebihi $(n+d)$ sehingga terjadi capital deepening. Pada $k_{1}$ tersebut, tingkat konsumsi per tenaga kerja sebesar $(d-b)$. Karena terjadi capital deepening maka tingkat output terus tumbuh akibat peningkatan capital per worker, peningkatan output tersebut berhenti hingga tercapai $s f(k)=(n+d)$, yaitu pada saat $\mathrm{k}^{*}, \mathrm{y}^{*}$. Keadaan ini disebut dengan steady state. Solow memprediksi bahwa tanpa peningkatan teknologi maka kemampuan suatu perekonomian untuk meningkatkan output per tenaga kerja melalui akumulasi kapital akan sangat dibatasi oleh interaksi antara diminishing return, willingness people to save, tingkat pertumbuhan penduduk, dan tingkat depresiasi kapital.

Peningkatan teknologi tersebut dapat ditunjukkan oleh fungsi produksi Cobb-Douglas sebagai berikut.

$$
Y=A_{t} K^{\alpha} L^{1-\alpha}
$$

$A_{t}$ adalah teknologi yang tergantung pada unsur waktu, dan Jika diasumsikan CRTS dan fungsi di atas dijadikan dalam bentuk output per worker, maka dapat diperoleh 
$\frac{Y}{L}=A\left(t_{0}\right)\left(\frac{K}{L}\right)=A\left(t_{0}\right)\left(\frac{K^{\alpha} L^{1-\alpha}}{L}\right)=A\left(t_{0}\right)\left(\frac{K}{L}\right)^{\alpha}$

Jika $\mathrm{y}=\mathrm{Y} / \mathrm{L}$ dan $\mathrm{k}=\mathrm{K} / \mathrm{L}$, maka dapat diperoleh:

$y=A\left(t_{0}\right) k^{\alpha}>>$

Gambar di bawah ini menujukkan perbedaan antara dampak capital deepening (yaitu peningkatan capital per worker) dengan dampak peningkatan teknologi.

Perubahan capital per worker hanya akan menyebabkan pergerakan sepanjang satu kurva fungsi produksi, sedangkan peningkatan teknologi akan menyebabkan peningkatan output dari satu kurva produksi ke kurva produksi lainnya, yaitu dari $A\left(t_{0}\right) k^{a}$ menjadi $A\left(t_{l}\right) k^{a}$.

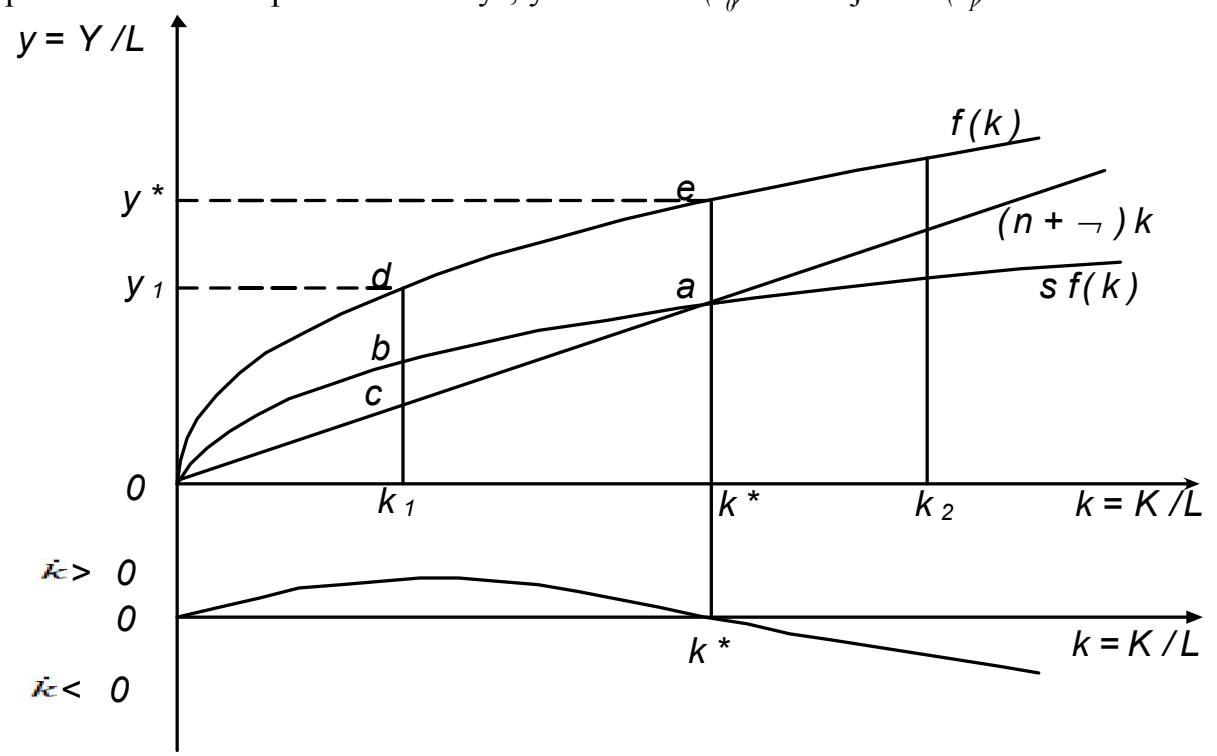

Sumber: Snowdon \& Vane, 2005: 608

Gambar 1: Model pertumbuhan Solow

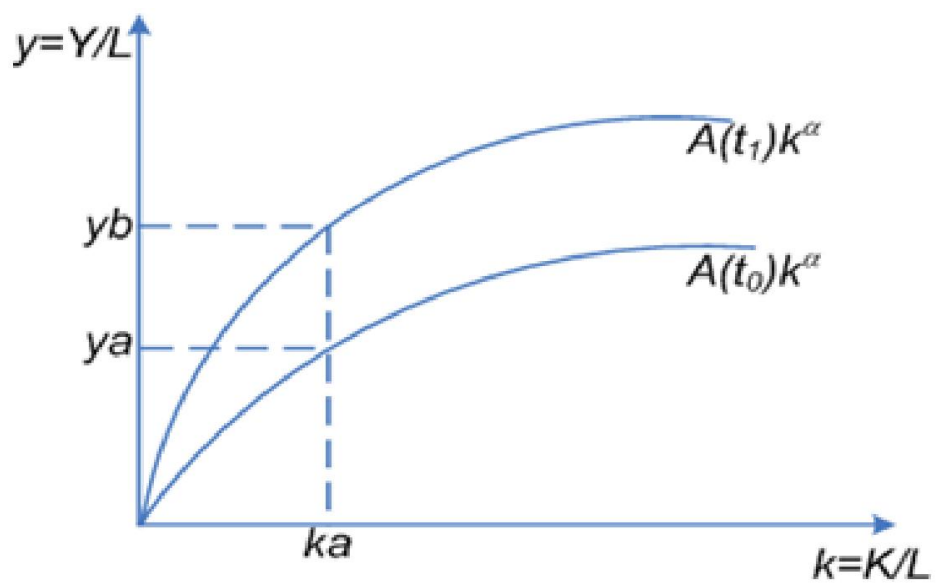

Sumber : Snowdon \& Vane, 2005: 610

Gambar 2: Dampak peningkatan teknologi 


\section{Journal of Indonesian Applied Economics}

Vol. 3 No. 1 Mei 2009, 77-88

Berdasarkan derivasi model pertumbuhan Solow di atas dapat diperoleh beberapa poin penting sebagai berikut: (1) perekonomian dalam jangka panjang akan mendekati steady state equilibrium, (2) steady state equilibrium tergantung pada tingkat depresiasi, pertumbuhan penduduk, dan tabungan, (3) tanpa ada peningkatan teknologi pertumbuhan output per worker tidak berkelanjutan, (4) peningkatan saving rate pada pertumbuhan output per worker bersifat temporer, dan (5) jika beberapa negara memiliki struktur yang mirip dalam konteks preferensi dan teknologi, maka negara berkembang akan tumbuh lebih cepat dari negara maju sehingga dapat terjadi konvergensi.

Kecepatan konvergensi atau sering disebut dengan $b$ ditunjukkan oleh persamaan berikut:

$\beta=(I-\alpha)(\delta+n+x)$.

Di mana $a$ adalah pangsa capital dalam fungsi produksi yang besarnya $0<\mathrm{a}<\mathrm{I}, d$ adalah tingkat depresiasi, $n$ adalah pertumbuhan penduduk, dan $x$ adalah tingkat pertumbuhan produktivitas.

Sala-i-Martin (1996) secara grafis menggambarkan hubungan antara $b$-convergence dan $s$ convergence sebagai berikut. Tiga gambar yaitu $3 \mathrm{a}, 3 \mathrm{~b}$, dan $3 \mathrm{c}$ memperlihatkan perilaku $\log P D B$ dua wilayah atau negara seiring dengan berjalannya waktu. Pada Gambar 3a, dengan menetapkan perspektif waktu dari mulai $(t)$ hingga $(t+T)$, perekonomian negara atau wilayah A pada waktu $(t)$ lebih maju dibandingkan perekonomian B. Ini artinya pada waktu $(t)$ terdapat dispersi tingkat nendanatan

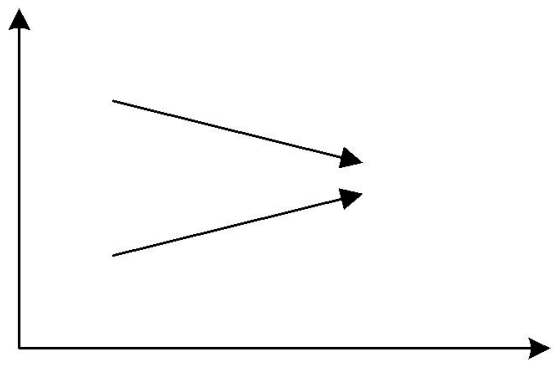

\section{Sumber: Sala-i-Martin (1996)}

\section{Gambar 3a. b-convergence dan s-convergence}

Pada Gambar 3a tersebut perekonomian A tumbuh lebih rendah (bahkan negatif) dibandingkan perekonomian B selama periode $(t)$ hingga $(t+T)$. Dalam keadaan tersebut dapat dinyatakan bahwa terdapat $b$-convergence. Selanjutnya, karena dispersi tingkat pendapatan pada $(t+T)$ lebih kecil dibandingkan pada $(t)$, maka dapat pula dinyatakan terdapat s-convergence. Berdasarkan kedaan pada Gambar 3a tersebut, maka necessary condition bagi terciptanya s-convergence adalah adanya b-convergence.

Lebih jauh Gambar $3 b$ memperlihatkan bagaimana perekonomian A dan B tidak mengalami $b$ convergence dan s-convergence. Pada gambar tersebut perekonomian A (kaya) mengalami pertumbuhan lebih tinggi dibandingkan perekonomian B (miskin). Selanjutnya, secara teoritis juga dimungkinkan perekonomian B (miskin) tumbuh lebih cepat relatif terhadap perekonomian A (kaya) tanpa adanya pengurangan dispersi tingkat pendapatan pada $(t+T)$. Keadaan tersebut diperlihatkan pada Gambar $3 c$. Ini artinya gambar tersebut memperlihatkan adanya $b$-convergence tanpa keberadaan -convergence.

Dalam analisis konvergensi, menurut Sala-i-Martin (1996) terbagi menjadi dua pendekatan yaitu absolute dan conditional convergence. Absolute b-convergence merujuk pada keadaan di mana perekonomian yang miskin akan tumbuh lebih tinggi dibandingkan perekonomian yang lebih kaya. Sedangkan absolute s-convergence menunjukkan penurunan dispersi tingkat pendapatan antar perekonomian maju dan miskin seiring dengan berjalannya waktu. 


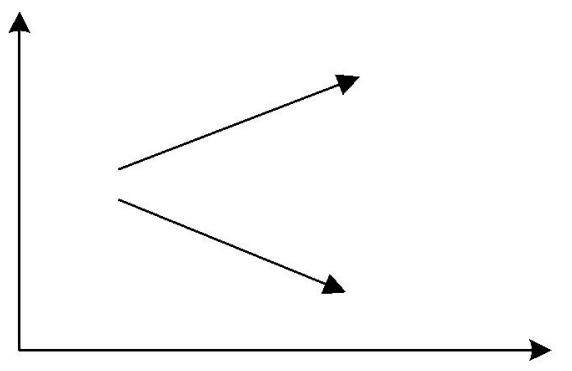

\section{Sumber: Sala-l-lviartin (1996)}

\section{Gambar 3b: non-existence of b-convergence dan s-convergence}

Conditional b-convergence merujuk pada keadaan di mana terdapat perbedaan struktural antar perekonomian setidaknya dalam aspek teknologi, saving rate, pertumbuhan penduduk dan faktor struktural lainnya yang pada akhirnya akan mempengaruhi kecepatan suatu perekonomian menuju tingkat steady state nya (seperti ditunjukkan persamaan 7). Oleh karena itu tingkat pertumbuhan yang akan dialami oleh suatu negara sangat tergantung pada posisi negara tersebut relatif terhadap steady state nya given faktor seperti a, $\mathrm{n}, \mathrm{x}$, dan $\mathrm{d}$. Secara empirik, conditional convergence ini dapat diakomodasi dalam model ekonometrik dengan melibatkan variabel yang secara spesifik dipandang membedakan satu perekonomian dengan perekonomian lainnya.

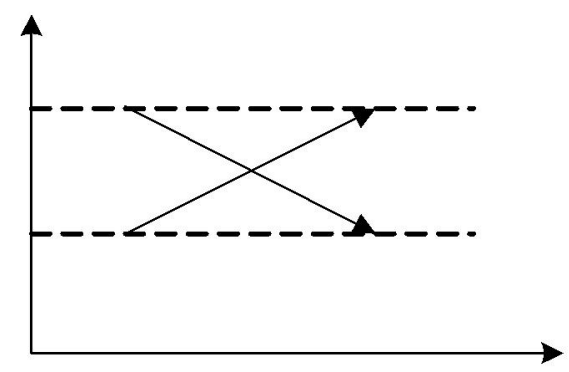

Sumber: Sala-i-Martin (1996)

Gambar 3c: existence of b-convergence dan non-existence of s-convergence

\section{Penelitian Sebelumnya}

Konsep konvergensi secara empiris diterapkan pada data produktivitas tenaga kerja dari 16 negara industri dalam Maddison (1982) yang dilakukan oleh Abramowitz (1986) dan Baumol (1986). Hasil penelitiannya menunjukkan bahwa semakin tingkat produktivitas tenaga kerja pada tahun 1870, semakin lambat pertumbuhan produktivitas terebut pada abad selanjutnya. Penelitian ini mendapat kritikan dari Romer (1986) dan DeLong (1988) yang menyatakan adanya permasalahan ex-post sample selection bias. Menurut Romer dan DeLong dengan menggunakan data milik Maddison yang menunjukkan suatu perekonomian mengalami industrialisasi secara ex-post yaitu sejak 1979. Ini artinya perekonomian yang tidak mengalami konvergensi tidak termasuk menjadi sampel. Setelah data Maddison dikembangkan sehingga melibatkan perekonomian yang telah menjadi negara industri sejak 1870 (ex-ante), maka hasil penelitian menunjukkan tidak adanya konvergensi di antara negara-negara tersebut.

Barro et al (1991) pada penelitian lainnya melakukan estimasi mengenai konvergensi dengan kerangka neoclassical growth model pada 73 wilayah di Eropa Barat sejak tahun 1950. Hasil estimasinya memperlihatkan bahwa terdapat konvergensi antar wilayah, meskipun tidak sesuai dengan hipotesis awal yang menyatakan bahwa $b$ konstan dengan berjalannya waktu. Pada model selanjutnya penggunaan dummy daerah (fixed effect model) juga mengkonfirmasi model sebelumnya 


\section{Journal of Indonesian Applied Economics}

Vol. 3 No. 1 Mei 2009, 77-88

yaitu adanya konvergensi dalam pendapatan per kapita antar daerah. Pada model terakhir yaitu dengan melibatkan dummy variable sektoral, menunjukkan bahwa $b$ konstan dengan berjalannya waktu.

Barro dan Sala-i-Martin (1992) melakukan penelitian untuk melihat keberadaan konvergensi pada 48 negara bagian di Amerika Serikat. Model yang digunakan mendasarkan diri pada neoclassical growth model dengan variabel per capita personal income sejak 1929 hingga 1988 dan variabel per capita PDRB selama periode 1963-1986. Perbedaan antara kedua nya adalah per capita personal income termasuk pendapatan individu dari perusahaan dalam bentuk dividen, sedangkan per capita PDRB termasuk profit perusahaan dan depresiasi. Hasil estimasinya menunjukkan bahwa terdapat konvergensi, di mana perekonomian yang tingkat pendapatan per kapita nya relatif lebih jauh dari keadaan steady state nya, cenderung memiliki tingkat pertumbuhan lebih tinggi. Pada hasil lainnya memperlihatkan bahwa bahkan dalam konteks mengontrol variabelvariabel yang dipandang sebagai pembeda antara satu negara bagian dengan negara bagian lainnya, seperti wilayah dan komposisi sektoral, hasilnya masih tetap mendukung konvergensi antar wilayah dengan kecepatan konvergensi yang hampir sama dengan model tanpa mengontrol variabel tersebut.

Coulombe dan Lee (1995) melakukan penelitian tentang konvergensi berbagai Propinsi di Kanada selama periode 1961-1991. Hasil estimasi menemukan bahwa terjadi konvergensi antar Propinsi dengan menggunakan beberapa variabel yang merepresentasikan output dan pendapatan per kapita. Ditemukan juga bahwa faktor yang mendorong konvergensi di antaranya adalah perdagangan antar Propinsi dan kebijakan pemerintah dalam bentuk subsidi dan pajak.

Sala-i-Martin (1996) melakukan penelitian tentang $b$-convergence dan $s$-convergence dengan menggunakan Summers-Heston data (1988) yang melibatkan 110 negara di dunia. Peneliti menggunakan dua definsi yaitu absolute dan conditional convergence. Dengan menggunakan data tahun 1960 hingga 1990, Sala-i-Martin tidak menemukan adanya absolute b-convergence dan s-convergence. Selanjutnya dengan menggunakan beberapa variabel kontrol, ditemukan adanya conditional b-convergence, dengan speed of conditional convergence sebesar $2 \%$ per tahun. Pada saat yang sama juga ditemukan adanya s-convergence, meskipun proses s-convergence berhenti pada pertengahan dekade 1970-an. Pada sub sampel negara OECD seperti Jepang, USA, Jerman, UK, Perancis, Italia, dan Spanyol ditemukan adanya absolute dan conditional b-convergence.

Cho (1996) dengan menggunakan Summers-Heston data (1988) yang mencakup 109 negara melakukan estimasi conditional convergence. Variabel kontrol yang digunakan untuk mengakomodasi heterogeneity adalah investment to GDP ratio dan population growth rate. Dengan menggunakan pendekatan panel regression ditemukan adanya permasalahan endogeniety bias problem sehingga hasil akhir menunjukkan tidak ditemukannya konvergensi antar negara. Hasil estimasi justru memperlihatkan bahwa negara maju tumbuh lebih cepat dengan mendorong investment to GDP ratio lebih tinggi dan tingkat pertumbuhan populasi yang rendah.

Carree dan Klomp (1997) mencoba melakukan estimasi tentang konvergensi pada 22 negara OECD selama periode 1960-1985 dengan memecah periode waktu 1950-1994 dan 1960-1985. Keduanya menggunakan pendekatan Monte Carlo simulation experiment untuk membuktikan kesimpulan Lichtenberg (1994) yang menyatakan tidak ada konvergensi pada perekonomian OECD tersebut. Hasil estimasi Carree dan Klomp justru memperlihatkan bahwa konvergensi terjadi dengan sampel dan periode waktu yang sama.

Matkowski dan Prochniak (2004) melakukan penelitian tentang konvergensi pendapatan dan konvergensi siklus bisnis pada CEE countries yang akan masuk dalam kelompok EU. Analisis didasarkan pada data 1993 hingga 2004. Hasil penelitian menunjukkan bahwa CEE countries mengalami konvergensi dalam konteks tingkat pendapatan. Di samping itu, ditemukan pula adanya sinkronisasi siklus bisnis antara CEE dengan negara kelompok EU. Konvergensi dan sinkronisasi siklus bisnis ini secara signifikan dipengaruhi oleh ketergantungan CEE countries pada pasar EU dalam perdagangan dan aliran modal.

Roy dan Bhattacharjee (2009) dengan menggunakan data Human Development Index (HDI) di berbagai wilayah India, melakukan estimasi tentang kecepatan konvergensi antar daerah. Untuk 
kepetingan analisis peneliti membagi periode waktu menjadi dua yaitu periode 1981-91 dan 199101 . Hasil estimasi menunjukkan bahwa terdapat $b$ convergence, namun pada saat yang sama ditemukan bahwa dispersi tingkat HDI antar daerah justru semakin besar dengan berjalannya waktu. Ini artinya tidak terjadi s convergence pada berbagai daerah.

\section{METODE PENELITIAN DAN ANALISIS DATA}

Terdapat beberapa konsep tentang konvergensi dalam literatur. Paper ini akan menggunakan dua konsep yang paling sering digunakan yaitu disebut dengan b-convergence dan s-convergence. b-convergence merujuk pada pergerakan setiap negara dalam distribusi statis dari pendapatan, sedangkan s-convergence melihat apakah distribusi pendapatan dunia yang diterima setiap negara semakin baik atau tidak.

b-convergence terjadi apabila negara miskin tumbuh perekonomiannya lebih cepat dari negara maju, sehingga dalam framework studi cross-section antar negara seharusnya ditemukan korelasi negatif antara tingkat pertumbuhan rata-rata dengan pendapatan awalnya (initial income). Jika Produk Domestik Bruto (PDRB) Kabupaten $i$ pada tahun $t$ dinotasikan dengan $y_{i t}$, maka pertumbuhan tahunan PDRB Kabupaten $i$ antara periode $\mathrm{t}$ hingga $(\mathrm{t}+\mathrm{T})$ dapat dituliskan sebagai berikut.

$\gamma_{i, t, t+T}=\frac{1}{T} \ln \frac{y_{i, t+T}}{y_{i, t}}=\frac{\ln y_{i, t+T}-\ln y_{i, t}}{T}, T>0$

Regresi terhadap persamaan di bahwa ini dapat dilakukan

$$
\gamma_{i, t, t+T}=\alpha+\beta \ln y_{i, t}+\varepsilon_{i}
$$

di mana jika $b$ bernilai negatif, maka terdapat kondisi $b$-convergence (Sala-i-Martin, 1996). Konvergensi ini dapat dalam bentuk absolute atau conditional terhadap satu atau beberapa variabel spesifik daerah. Jika terdapat faktor atau variabel yang spesifik maka persamaan (8) harus ditambah dengan variabel independen yang mencerminkan perbedaan keadaan steady state setiap daerah.

Sedangkan s-convergence dapat didefinisikan beberapa daerah dapat terkonvergensi dalam konteks $s$ jika dispersi PDRB antar daerah berkurang dari waktu ke waktu yaitu:

$$
\sigma_{t+T}<\sigma_{t}
$$

Di mana s adalah standar deviasi dari variabel yang diamati pada periode waktu tertentu.

Pada paper ini digunakan konsep absolute b-convergence dan s-convergence yang tidak melihat adanya perbedaan yang secara spesifik membedakan satu daerah dengan yang lain. Dalam penelitian selanjutnya dapat diidentifikasi faktor seperti teknologi, human capital, atau bahkan saving rate yang menjadi pembeda dari setiap perekonomian, sehingga dapat mengakomodasi perbedaan struktur perekonomian. Hal ini tentu saja dapat berdampak pada koefisien $b$ pada persamaan (9) yang menunjukkan speed of convergence dari berbagai perekonomian.

Untuk kepentingan analisis, paper ini akan menggunakan tiga wilayah di Pulau Jawa yaitu masing-masing Propinsi Jawa Timur, Jawa Tengah, dan Jawa Barat. Data yang digunakan adalah Produk Domestik Bruto (PDRB) pada harga konstan tahun 2000 Kabupaten di ke-tiga Propinsi tersebut untuk periode waktu 2004-2007. Ini artinya pendekatan kuantitatif yang digunakan adalah panel data.

Absolute b-convergenceakan diestimasi dengan menggunakan model ekonometrik seperti pada persamaan (9), sedangkan s-convergence seperti pada persamaan (10) akan dihitung dengan menggunakan formula:

$$
S=\sqrt{\frac{1}{n} \sum_{i=1}^{n}\left(X_{i}-\bar{X}\right)^{2}}
$$


Pada estimasi model ekonometrik akan digunakan tiga teknik yaitu Pool Least Square (PLS), Fixed Effect Model (FEM), dan Random Effect Model (REM). Setelah diestimasi dengan tiga teknik tersebut, akan dipilih model yang terbaik dengan menggunakan criteria uji $\mathrm{F}$ dan uji Hausman.

Uji F digunakan untuk memilih teknik yang terbaik antara PLS dan FEM. Formula uji F tersebut adalah sebagai berikut:

$$
F=\frac{\left(R_{u r}^{2}-R_{r}^{2}\right) /(m)}{\left(1-R_{u r}^{2}\right) /(n-k)}
$$

Restricted regression ( $r$ ) dan unrestricted regression (ur) masing-masing mengacu pada hasil estimasi PLS dan FEM dengan menggunakan dasar hipotesis nol bahwa teknik PLS lebih baik dari FEM.

Sedangkan untuk menentukan teknik FEM atau REM yang terbaik untuk analisis, dapat digunakan Hausman Specification Test dengan hipotesis nol: REM konsisten dan efisien, dan hipotesis alternatif sebaliknya yaitu FEM yang konsisten dan efisien. Hausman Specification test ini adalah berdasarkan Chi-Square distribution.

\section{HASIL DAN PEMBAHASAN}

Berdasarkan informasi yang diperoleh dari tabel 1 di atas, dapat diperoleh beberapa poin sebagai berikut. Pertama, dalam konteks penentuan ada atau tidaknya b-convergence, teknik FEM menunjukkan koefisien 0,054 , yang artinya terjadi perkembangan divergen mengenai tingkat pendapatan antar kabupaten. Semakin tinggi PDRB suatu Kabupaten diiringi dengan semakin tingginya pertumbuhan PDRB daerah tersebut. Kedua, teknik PLS dan REM meskipun menunjukkan terjadinya $b$-convergence, namun koefisiennya tidak signifikan. Ketiga, berdasarkan Hausman specification test, Hipotesis alternatif yaitu FEM konsisten dan efisien tidak dapat ditolak. Selanjutnya nilai adjusted R2 dan Durbin-Watson pun lebih baik pada teknik FEM daripada REM. Ini artinya REM dapat dikesampingkan dari analisis konvergensi selanjutnya. Keempat, hasil pengujian melalui F-test untuk teknik PLS dan FEM terlihat tidak robust. Hal ini ditunjukkan dengan nilai $F$ test hitung yang sangat dekat dengan batas yang ditunjukkan pada $F$ tabel. Nilai $F$ hitung dengan menggunakan formula pada persamaan (12) sebesar 1,3, sedangkan $\mathrm{F}$ tabel dengan numerator 37 dan denumerator 109, pada derajat kepercayaan 90\% adalah 1,37. Oleh karena itu, diperlukan pertimbangan lain untuk menentukan teknik mana yang lebih baik. Indikator lain yang dapat digunakan adalah adjusted R2 dan nilai D-W statistik. Berdasarkan dua indikator tersebut, maka teknik FEM lebih baik.

Berikut ini adalah hasil estimasi dengan menggunakan tiga teknik estimasi data panel pada seluruh Kabupaten di Propinsi Jawa Timur 
Tabel 1. Hasil Estimasi Absolute Convergence Pada Seluruh Kabupaten di Propinsi Jawa Timur

\begin{tabular}{c|c|c|c}
\hline & LPS & FEM & REM \\
\hline$\beta$ & $\begin{array}{c}-0.001390 \\
(-1.207731)\end{array}$ & $\begin{array}{c}0.053877 \\
(3.162019)^{*}\end{array}$ & $\begin{array}{c}-0.001369 \\
(-1.149203)\end{array}$ \\
\hline$\sigma$-convergence & \multicolumn{3}{|c}{ SD $07^{>}$SD $_{04}(11383.28>9$} \\
No $\sigma$-convergence \\
\hline Adj R2 & 0.003110 & $0.083639^{* *}$ & 0.023628 \\
\hline D-W Stat & 1.298880 & $1.772471^{* * *}$ & 1.352118 \\
\hline Hausman test & - & $144.89401^{* * * *}$ & 144.89401 \\
(REM vs FEM) & & (accept FEM) & (accept FEM) \\
\hline $\begin{array}{c}\text { F-test specification } \\
\text { (PLS vs FEM) }\end{array}$ & $\begin{array}{c}1,3^{* * * * *} \\
\text { (accept PLS) }\end{array}$ & $\begin{array}{c}1,3 \\
\text { (accept PLS) }\end{array}$ \\
\hline
\end{tabular}

Keterangan:

*signifikan dengan $\mathrm{a}=1 \%$ menunjukkan adanya tidak adanya $b$ convergence

** merupakan model terbaik dari indicator koefisien determinasi

*** merupakan model terbaik dari indicator Durbin-Watson yang mendekati 2

**** merupakan model terbaik menurut Hausman specification test

$* * * * *$ merupakan model terbaik menurut $\mathrm{F}$-test spesifikasi model ( $\mathrm{F}$ tabel $90 \%=1,37)$. Jika menggunakan 75\% maka FEM yang terbaik (memerlukan indicator lain untuk memilih LPS atau FEM)

Berdasarkan poin pertama, kedua dan keempat, maka dapat disimpulkan bahwa dalam perekonomian Jawa Timur tidak dapat ditemukan adanya $b$-convergence. Meskipun demikian, keitdakhadiran b-convergence ini bersifat tidak robust karena tidak didukung oleh hasil dari teknik PLS maupun REM. Untuk meningkatkan robustnest hasil, penelitian selanjutnya dapat menggunakan control variable bagi heterogeinity yang ada dalam seluruh kabupaten di Jawa Timur. Kelima, dalam konteks s-convergence dapat disimpulkan bahwa tidak ada kecenderungan adanya konvergensi karena standar deviasi atau varians tingkat pendapatan antar kabupaten cenderung semakin membesar dengan berjalannya waktu.

Tabel 2 memperlihatkan hasil estimasi pada perekonomian Jawa Tengah. Berdasarkan tabel 2 tersebut terdapat beberapa poin yang dapat disimpulkan. Pertama, teknik PLS dan REM mengkonfirmasi tentang ketidakberadaan $b$ convergence pada perekonomian Jawa Tengah yang ditunjukkan oleh koefisien $b$ yang positif dan signifikan, sedangkan koefisien b pada FEM tidak signifikan. Kedua, berdasarkan pengujian spesifikasi melalui $\mathrm{F}$ test diperoleh hasil bahwa FEM lebih baik dari PLS. Ketiga, hasil Hausman specification test, maka REM merupakan model yang lebih konsisten dan efisien dibandingkan dengan FEM. Oleh karena itu, berdasarkan poin dua dan tiga, maka inferensi tentang keberadaan $b$ convergence dapat didasarkan pada hasil estimasi REM. Keempat, efisiensi dan konsistensi hasil estimasi REM didukung oleh adjusted R2 yang relatif lebih tinggi dibandingkan dengan adjusted R2 pada PLS dan FEM. Kelima, dalam konteks $s$ convergence tidak ditemukan adanya konvergensi karena standar deviasi tingkat pendapatan antar kabupaten pada tahun 2007 lebih tinggi dari standar deviasi pada tahun 2004.

Tabel 3 di bawah ini memperlihatkan hasil estimasi untuk membuktikan keberadaan absolute convergence untuk perekonomian Jawa Barat. Beberapa hal dapat dinyatakan sebagai berikut. Pertama, satu-satunya koefisien yang signifikan hanya ditunjukkan oleh fixed effect model. Kedua, berdasarkan hasil Hausman test diperoleh hasil bahwa model yang terbaik untuk Jawa Barat dalam mengetahui keberadaan konvergensi adalah FEM. Ketiga, dalam konteks model FEM dan PLS pun, FEM lebih konsisten dan efisien seperti diperlihatkan oleh hasil uji F. Keempat, berdasarkan 
Journal of Indonesian Applied Economics

Vol. 3 No. 1 Mei 2009, 77-88

Tabel 2. Hasil Estimasi Absolute Convergence Pada Seluruh Kabupaten di Propinsi Jawa Tengah

\begin{tabular}{c|c|c|c}
\hline & LPS & FEM & REM \\
\hline$\beta$ & $\begin{array}{c}0.001495^{*} \\
(2.749)\end{array}$ & $\begin{array}{c}-6.26 \times 10^{-07} \\
(-0.59)\end{array}$ & $\begin{array}{c}0.0016^{* *} \\
(2.175)\end{array}$ \\
\hline$\sigma$-convergence & \multicolumn{3}{|c}{$\mathrm{SD}_{07}>\mathrm{SD}_{04}(4273.92>3673.48)$} \\
No $\sigma$-convergence \\
\hline Adj R2 & 0.045 & 0.284 & $0.304^{* * *}$ \\
\hline D-W Stat & 0.867 & 1.55 & 1.188 \\
\hline $\begin{array}{c}\text { Hausman test } \\
\text { (REM vs FEM) }\end{array}$ & - & 0.734 \\
\hline $\begin{array}{c}\text { F-test specification } \\
\text { (PLS vs FEM) }\end{array}$ & 2.285 & $\begin{array}{c}2.285^{* * * * *} \\
\text { (accept FEM) }\end{array}$ & (accept REM) \\
\hline
\end{tabular}

*signifikan dengan $\mathrm{a}=1 \%$ menunjukkan tidak adanya convergence

** signifikan dengan a $=5 \%$ menunjukkan tidak adanya $b$ convergence

*** merupakan model terbaik dari indicator R2

**** REM merupakan model terbaik menurut Hausman specification test

$* * * * *$ merupakan model terbaik menurut $\mathrm{F}$-test spesifikasi model $(\mathrm{F}$ tabel $95 \%=1,55)$. Karena $\mathrm{F}$ hitung $>\mathrm{F}$ tabel, maka keputusannya adalah tidak dapat menolak jika FEM adalah estimator yang efisien dan konsisten

Hausman test dan $F$ test maka model yang paling baik adalah FEM. Hal ini juga didukung oleh kriteria R2 yang nilainya paling tinggi dibandingkan REM dan PLS. Berdasarkan hasil estimasi FEM, berbagai Kabupaten di Jawa Barat tidak mengalami konvergensi. Selanjutnya, seperti halnya kasus sebelumnya, hasil penghitungan standar deviasi memperlihatkan tidak adanya s-convergence di berbagai Kabupaten di Jawa Barat. Ini artinya gap tingkat pendapatan terus melebar.

Tabel 3. Hasil Estimasi Absolute Convergence Pada Seluruh Kabupaten di Propinsi Jawa Barat

\begin{tabular}{|c|c|c|c|}
\hline & LPS & FEM & REM \\
\hline$\beta$ & $\begin{array}{c}-0.000299 \\
(0.8979)\end{array}$ & $\begin{array}{l}0.066484^{*} \\
(2.442826)\end{array}$ & $\begin{array}{c}-2.29 \mathrm{E}-05 \\
(2.175)\end{array}$ \\
\hline$\sigma$-convergence & \multicolumn{3}{|c|}{$\begin{array}{c}\mathrm{SD}_{07}>\mathrm{SD}_{04}(4273.92>3673.48) \\
\text { No } \sigma \text {-convergence }\end{array}$} \\
\hline Adj R2 & -0.012 & $0.173^{\star *}$ & 0.122 \\
\hline D-W Stat & 2.367 & 3.332 & 1.188 \\
\hline $\begin{array}{l}\text { Hausman test } \\
\text { (REM vs FEM) }\end{array}$ & - & $\begin{array}{c}6.603^{* * * *} \\
\text { (accept FEM) }\end{array}$ & $\begin{array}{c}6.603 \\
\text { (accept FEM) }\end{array}$ \\
\hline $\begin{array}{l}\text { F-test specification } \\
\text { (PLS vs FEM) }\end{array}$ & $\begin{array}{c}1.83 \\
\text { (accept FEM) }\end{array}$ & $\begin{array}{c}1.83 * * * * * \\
\text { (accept FEM) }\end{array}$ & - \\
\hline
\end{tabular}


*signifikan dengan a $=5 \%$ menunjukkan tidak adanya convergence

** merupakan model terbaik dari indicator R2

*** FEM merupakan model terbaik menurut Hausman specification test

$* * * * *$ merupakan model terbaik menurut $\mathrm{F}$-test spesifikasi model $(\mathrm{F}$ tabel $95 \%=1,75)$. Karena $\mathrm{F}$ hitung $>\mathrm{F}$ tabel, maka keputusannya adalah tidak dapat menolak jika FEM adalah estimator yang efisien dan konsisten

\section{E. KESIMPULAN}

Penelitian ini bertujuan untuk menentukan keberadaan absolute convergence dalam bentuk $b$ convergence dan s-convergence. Konsep konvergensi merupakan implikasi penting dari teori pertumbuhan neoklasik yang menyatakan bahwa jika perekonomian memiliki tingkat produktivitas, depresiasi kapital, dan tingkat pertumbuhan yang sama, maka akan terdapat kecenderungan terbentuknya konvergensi tingkat pendapatan antar negara atau wilayah. Hal ini tercermin dalam tingkat pertumbuhan negara berkembang lebih tinggi daripada negara maju sebagai konsekuensi dari asumsi diminishing return pada capital-labor ratio.

b-convergence terjadi apabila negara miskin memiliki pertumbuhan lebih tinggi dari negara maju, sedangkan s-convergence merujuk pada keadaan di mana dengan berjalannya waktu maka dispersi atau gap tingkat pendapatan antar negara atau wilayah semakin kecil. b-convergence merupakan necessary condition bagi terciptanya s-convergence. Konvergensi pun dapat dalam bentuk absolute maupun conditional. Conditionality ini tercipta jika ditemukan faktor-faktor yang secara mendasar membedakan satu perekonomian dengan perekonomian lainnya, seperti tingkat tabungan, produktivitas, hingga aspek network externality dan aglomerasi.

Penelitian konvergensi ini didasarkan pada data 3 Propinsi di Pulau Jawa yaitu Jawa Timur, Jawa Tengah, dan Jawa Barat. Periode waktu yang digunakan adalah 2004-2007 dengan menggunakan PDRB harga konstan tahun 2000. Hasil penelitian memperlihatkan bahwa di ketiga perekonomian tidak terdapat $b$-convergence maupun s-convergence. Di ketiga Propinsi tersebut, setiap peningkatan PDRB Kabupaten selalu disertai dengan peningkatan pertumbuhan PDRB dan peningkatan gap tingkat antar satu Kabupaten dengan Kabupaten lainnya. Ini artinya, hasil estimasi justru mengkonfirmasi terjadinya perkembangan ekonomi secara divergen antar Kabupaten di ketiga Propinsi tersebut.

Studi konvergensi selanjutnya dapat diarahkan pada pengakomodasian faktor-faktor yang secara signifikan membedakan satu daerah dengan daerah lainnya, sehingga dapat diketahui lebih jauh determinan konvergensi atau divergensi antar daerah.

\section{DAFTAR PUSTAKA}

Abramowitz, M (1986). "Catching up, forging ahead, and falling behind." Journal of Economic History. Vol 46. p. 385-406

Abramowitz (1956). "Resource and output trends in the US since 1870, American Economic Review. Vol. 46. P. 5-23

Barro, R. J dan Sala-i-Martin, X (1992). “Convergence”. Journal of Political Economy. Vol. 100. P. 223-251

Barro, R. J., X. Sala-i-Martin., O. J. Blanchard, R. E. Hall (1991). "Convergence across states and regions." Brooking papers on economic activity. Vol.1991. P. 107-182

Baumol, W. J (1986). "Productivity growth, convergence, and welfare: what the long run data show." American Economic Review. Vol. 76. P. 1072-85 
Ben-David D. (2000). "Trade, Growth and Disparity Among Nations", in: Trade and Poverty, Geneva: WTO

Carree, M dan L. Klomp (1997). "Testing the convergence hypothesis: A comment." The Review of Economics and Statistics. Vol. 79. P. 683-686

Coulombe, S dan F. C. Lee (1995). "Convergence across Canadian provinces, 1961-1991.” The Canadian Journal of Economics. Vol. 28. P. 886-898

Cho, D (1996). "An alternative interpretation of conditional convergence result." Journal of Money, Credit and Banking. Vol. 28. P669-681

DeLong (1988). "Productivity growth, convergence \& welfare: comment." American Economic Review. Vol. 78. P. 1138-54

Matkowski, Z dan M. Prochniak (2004). "Real economic convergence in the EU accession countries." International Journal of Econometrics and Quantitative Studies. Vol 1-3

Romer, P.M. (1986). “Increasing Returns and Long-Run Growth.” Journal of Political Economy. Vol. 94. P. 1002-1027

Roy, H dan K. Bhattacharjee (2009). "Convergence of human development across Indian states." IGIDR Project Report Series.

Sala-i-Martin, X. (1996). "The Classical Approach to Convergence Analysis." Economic Journal. Vol. 106. P. 1019-1036

Snowdon, Brian \& Howard, R. Vane (2005). Modern Macroeconomics: Its origin, development and current state, Edward Elgar Publishing limited, UK

Solow, R. (1956). "A Contribution to the Theory of Economic Growth." Quarterly Journal of Economics, vol. 70. P. 65-94.

Solow, R. (1957). "Technical Change and the Aggregate Production Function." Review of Economics and Statistic. Vol. 39. P. 312-320.

Swan, T. W (1956). "Economic growth and capital accumulation.” Economic Record. Vol. 32. P. $334-61$ 